Vol 2 No 2 Desember 2021

Jurnal AlphaEuclidEdu

Received: 02/03/2021; Resived: 23/09/2021; Accepted: 28/12/2021

\title{
ANALISIS LITERASI NUMERASI PADA MATERI PERSAMAAN DAN PERTIDAKSAMAAN NILAI MUTLAK LINEAR SATU VARIABEL DIKAJI DARI KECERDASAN EMOSIONAL
}

\author{
Esa Sandi Putri, Edy Yusmin, Asep Nursangaji \\ Program Studi Pendidikan Matematika FKIP Untan Pontianak \\ Email:esasandiputri01@gmail.com
}

\begin{abstract}
This study aims to determine numeracy literacy in the material equations and inequalities of the absolute value assessed from the emotional intelligence of students at SMA Panca Setya Sintang. The method used in this research is descriptive with a case study research. The subjects in this study were students of grade X IPA 3 with a total of 17 students. The object to be researched is numeracy literacy in the material equations and inequality of the absolute linear value of one variable assessed from the emotional intelligence of students. The techniques used in data collection are questionnaires, numeracy literacy tests and interviews. The results obtained from this study that there were four students who had high levels of emotional intelligence and tended to have high numeracy literacy, eleven students had moderate emotional intelligence and also varied numeracy literacy with one student with good numeracy literacy, six students with good numeracy and four students with poor numeracy, and two students who had low levels of emotional intelligence and had low numeracy literacy.
\end{abstract}

Keywords: Numeracy Literacy, Emotional Intelligence, Equations And Inequalities Of The Absolute Value

\section{Pendahuluan}

Matematika merupakan mata pelajaran yang ada di setiap tingkatan pendidikan mulai dari Pendidikan Anak Usia Dini, Taman Kanak-Kanak, SD, SMP, maupunSMA. Dari tingkatan pendidikan paling awal anak-anak mulai dikenalkan dengan matematika. Misalnya pada anak usia dini mulai dikenalkan bilangan sederhana mulai dari 1 sampai 10. Matematika diharapkan dapat memberikan sumbangan dalam meningkatkan kemampuan peserta didik. Dalam hal ini telah dilakukannya berbagai upaya oleh pemerintah untuk meningkatkankemampuan peserta didik, salah satudiantaranya adalah merumuskan tujuan pendidikan. Pada konteks ini kita membahas tentang pembelajaran matematika maka tujuan dari pembelajaran matematika menurut Peraturan Menteri Pendidikan dan Kebudayaan Republik Indonesia Nomor 22 Tahun 2016 mengenai tujuan pembelajaran matematika, yakni (1) memahami konsep matematika, mendeskripsikan bagaimana keterkaitan antara konsep matematika dan menerapkan konsep secara efisien, luwes, akurat, dantepat dalam memecahkan masalah, (2) menalar pola sifat dari matematika, mengembangkan atau memanipulasi matematika dalam menyusun argumen, merumuskan bukti, atau mendeskripsikan argumen atau pernyataan matematika, (3) memecahkan masalah matematika yang meliputi kemampuan memahami masalah, menyusun model penyelesaian matematika, menyelesaikan model matematika, dan memberikan solusi yang tepat, dan (4) mengkomunikasikan argumen atau gagasan dalam bentuk tabel, diagram, simbol, ataupun media lainnya yang dapat memperjelas permasalahan ataupun keadaan. Tujuan dari pembelajaran matematika di 
Vol 2 No 2 Desember 2021

Jurnal AlphaEuclidEdu

Received: 02/03/2021; Resived: 23/09/2021; Accepted: 28/12/2021

atas sejalan dengan kemampuan literasi matematika yang sedang hangat diperbincangkan dalamkalangan pendidikan matematika internasional (Elviani, 2020).

Di dalam dunia pendidikan internasional peserta didik dituntut untuk dapat menyelesaikan persoalan matematika yang ada didalam kehidupan sehari-hari melalui kemampuan literasi matematika yang ada. Namun, kondisi pembelajaran matematika yang ada di Indonesia dapat dikatakan masih memiliki mutu pendidikan yang rendah jika dilihat dari kompetensi yang ada. Menurut berita Edukasi Kompas bahwa skor literasi yang ada di Indonesia berada di bawah literasi rata-rata skor PISA negara anggota OECD, yang mana skor rata rata ialah 489 sedangkan skor Indonesia 379 (Kompas.com, 2019). Hal ini menunjukan pentingnya literasi dalam menunjang pembelajaran matematika yang ada di sekolah (Panjaitan et al., 2021); (Fitriawan, 2021).

Secara umum literasi merupakan kemampuan dalam membaca, menulis, berbicara dan penggunaan bahasa. Literasi juga dapat dikaitkan dengan matematika. Literasi matematika merupakan kemampuan peserta didik untuk merumuskan, menerapkan dan menafsirkan matematika dalam bentuk konteks yang meliputi penalaran matematis dan penggunaan fakta, prinsip, konsep dan prosedural untuk mendeskripsikan suatu kejadian (OECD, 2016: 65); (Darmawati, 2020). Dalam literasi matematika terdapat berbagai macam literasi, salah satunya adalah literasi numerik atau dikenal juga literasi numerasi. Literasi numerasi adalah kemampuan seseorang dalam menggunakan angka dan simbol-simbol dalam matematika dalam bentuk kontekstual, menganalisis informasi dalam berbagai bentuk dan menginterpretasi serta mengkomunikasikan hasil analisis untuk mengambil kesimpulan (dalam Gerakan Literasi Nasional 2017: 3). Keterampilan literasi numerasi sangat di perlukan dalam kehidupan sehari-hari, dengan menggunakan angka dan simbol yang ada dikehidupan sehari-hari untuk menyelesaikan suatu permasalahan.

Literasi numerasi memiliki perbedaan dengan matematika, dimana pengetahuan matematika saja tidak membuat seseorang memiliki kemampuan literasi numerasi namun literasi numerasi mencakup keterampilan mengaplikasikan konsep matematika dalam bentuk kontekstual. Jadi jika seseorang memiliki kemampuan literasi baik maka keterampilan matematika baik pula namun sebaliknya jika kemampuan matematika baik belum tentu kemampuan literasi seseorang baik pula dikarenakan kemampuan literasi numerasi memerlukan tingkat berpikir yang cukup tinggi. Dari pengertian literasi numerasi sendiri dapat dilihat pembelajaran matematika memerlukan kemampuan berpikir yang cukup tinggi. Menurut hasil wawancara singkat peneliti dengan salah seorang guru matematika yang ada di SMA Panca Setya Sintang pada tanggal 29 Agustus 2020 melalui via whatsapp, permasalahan yangada di sekolah saat ini peserta didik masih sulit untuk menyelesaikan soal-soal kontekstual. Peserta didik mampu menyelesaikan permasalahan rutin atau soal-soal yang tidak berbentuk kontekstual. Salah satu contohnya pada materi persamaan dan pertidaksamaan nilai mutlak linear satu variable peserta didik sudah mampu mencari penyelesaian dari $|2 x-7|=3$, namun masih belum mampu menyelesaikan permasalahan kontekstual dari materi ini dan mengkomunikasikan kepada peserta didik lainnya. Selain itu faktor yang dapat mempengaruhi pembelajaran matematika ialah kecerdasan emosional seseorang, dimana kemampuan seseorang menguasai emosi dirinya dalam memahami permasalahan matematika dan cara seseorang berinteraksi dengan sesamanya dalam 
Vol 2 No 2 Desember 2021

Jurnal AlphaEuclidEdu

Received: 02/03/2021; Resived: 23/09/2021; Accepted: 28/12/2021

mengkomunkasikan permasalahan matematika yang ada.

Menurut Wardono dan Kurniasih (2015) salah satu upaya guru dalam meningkatkan kemampuan literasi matematika peserta didik adalah dengan melakukan inovasi pembelajaran, sehingga proses pembelajaran dapat meningkatkan kecerdasan emosional peserta didik. Menurut hasil observasi peneliti terhadapguru yang mengajar banyak peserta didik yang kurang percaya diri sehingga menjadi faktor penghambat dalam memahami materi yang disampaikan guru. Pada saat peserta didik mulai mendengarkan materi yang disampaikan oleh guru, ada peserta didik yang tidak memahami namun tidak punya kepercayaan diri untuk bertanya. Selain kurang percaya diri masalah yangdialami peserta didik ialah kurangnya motivasi dalam pembelajaran.

Pada saat mengerjakan soal banyak peserta didik yang mengalami kesulitan, namun tidak ada usaha untuk mengerjakan soal tersebut. Padahal jika peserta didik tersebut ada keinginan mengerjakan soal yang dianggap sulit itu akan dapat terselesaikan. Namun kebanyakan peserta didik menyerah terlebih dahulu dikarenakan tidak bisa menjawab. Terlebih pada kondisi sekarang, pembelajaran dilakukan secara daring dan kebanyakan guru mengalami kesulitan dalam mengajar dikarenakan kurangnya respon peserta didik dalam proses pembelajaran. Dapat dilihat pada saat pembelajaran daring peserta didik kurang memiliki kesadaran diri untuk mengikuti pembelajaran. Percaya diri, mudah menyerah dan kesadaran diri termasuk ke dalam kecerdasan emosional, yang mana kecerdasan emosional sangat berhubungan dengan literasi, jika seseorang memiliki kecerdasan emosional tinggi dapatmembantu seseorang tersebut dalammemahami soal matematika yang berkaitan dengan literasi numerasi.

Menurut Aunurrahman (2008: 69) kecerdasan emosional tidak kalah penting dengan kecerdasan akademik, kecerdasan emosional membuat seseorang mampu melihat masalah, mampu mengatasi kegagalan dan akan mencapai kesuksesan. Jadi dengan dimilikinya kecerdasan emosional yang baik dapat membantu seseorang mencapai kesuksesannya. Kemampuan literasi numerasi merupakan kemampuan berpikir matematika tingkat tinggi, namun pada kenyataannya kemampuan berpikir matematika peserta didik masih rendah. Menurut Goleman(dalam Prawira, 2011: 159) kesuksesan peserta didik didukung dari $20 \%$ kecerdasan akademik dan 80\% merupakan kecerdasan lain yang disebut kecerdasan emosional. Salovery and Mayer (dalam Prawira, 2011: 113) kecerdasan emosional yaitu kemampuan untuk mengenali diri sendiri secara tepat, kemampuan memotivasi diri, kemampuan mengenali emosi orang lain dan kemampuan menjalin hubungan dengan orang lain. Jadi jika peserta didik memiliki kecerdasan emosional yang baik maka peserta didik tersebut dapat menyelesaikan permasalahan matematika yang menuntut peserta didik memiliki kemampuan berpikir matematika tingkat tinggi. Atau dapat diperjelas jika peserta didik memiliki kecerdasan emosional baik maka kemampuan literasi peserta didik tersebut juga baik (Fitriawan, 2004).

\section{Metode Penelitian}

Metode yang digunakan dalam penelitian ini adalah metode deskriptif dengan bentuk penelitian studi kasus. Subjek dalam penelitian ini adalah peserta didik kelas X IPA 3 SMAS Panca Setya Sintang sebanyak 17 orang. Sedangkan objek dalam penelitian ini adalah literasi numerasi pada materi persamaan dan pertidaksamaan nilai mutlak linear satu variabel dikaji dari kecerdasan emosionl peserta didik. Teknik 
Vol 2 No 2 Desember 2021

Jurnal AlphaEuclidEdu

Received: 02/03/2021; Resived: 23/09/2021; Accepted: 28/12/2021

pengumpulan data dalam penelitian ini adalah teknik tes, angket dan wawancara. Prosedur penelitian dalam penelitian ini terdapat 3 tahap yaitu: tahap persiapan, tahap pelaksanaan dan tahapakhir.

Tahap Persiapan

Dalam tahapan persiapan, kegiatan yang dilakukan adalah (1) menyusun desain penelitian, (2) membuat instrumenpenelitian berupa angket kecerdasan emosional, kisikisi soal tes, soal tes literasi numerasi pada materi persamaan dan pertidaksamaan nilai mutlak, alternatif penyelesaian, pedoman indikator literasi numerasi, dan pedoman wawancara, (3) melakukan validasi instrument, (4) merevisi instrument berdasarkan hasil validasi, (5) membuat google classroom, (6) melakukan uji coba instrument penelitian menggunakan classroom, (7) menganalisis data hasil uji coba, (8) merevisi instrumen penelitian berdasarkan hasil uji coba

\section{Tahap Pelaksanaan}

Dalam tahap pelaksanaan dilakukan beberapa kegiatan yaitu: (1) membagikan link dan kode classroom kepada peserta didik, (2) memberikan angket kecerdasan emosional di google classroom kepada peserta didik, (3) memberikan soal tes literasi numerasi pada materi persamaan dan pertidaksamaan nilai mutlak linear satu variable di google classroom kepada peserta didik, (4) menganalisis hasil angket kecerdasan emosional, (5) mengelompokan peserta didik menurut tingkatan kecerdasan emosional peserta didik yaitu tinggi, sedangdan rendah, (6) menganalisis hasil tesliterasi numerasi, (7) melakukan wawancarakepada 3 orang peserta didik yang terdiri dari 1 orang peserta didik yang memiliki kecerdasan emosional tingkat tinggi, 1 orang peserta didik yang memiliki kecerdasan emosional tingkat sedang dan 1 orang peserta didik yang memiliki kecerdasan emosional tingkat rendah, (8) melakukan analisis terhadap hasil wawancara, (9) mendeskripsikan hasilpengolahan data, (10) menarik kesimpulan untuk menjawab permasalahan berdasarkan rumusan masalah.

\section{Tahap Akhir}

Dalam tahapan akhir kegiatan ini yang akan dilakukan adalah menyusun laporan penelitian.

\section{Hasil Penelitian dan Pembahasan \\ Hasil Penelitian \\ Angket Kecerdasan Emosional}

Salah satu instrumen dalam pengumpulan data yang digunakan adalah angket kecerdasan emosional. Angket kecerdasan emosional digunakan untuk mengetahui tingkatan kecerdasan emosional peserta didik. Angket diberikan kepada 17 peserta didik di kelas X IPA 3 SMAS Panca Setya Sintang. Hasil angket dapat dilihat pada tabel berikut.

Tabel 1. Jumlah Skor dan Kategori Kecerdasan Emosional Peserta Didik

\begin{tabular}{|c|c|c|c|}
\hline No & Nama & Skor & Kategori \\
\hline 1 & ATA & 61,3 & Sedang \\
\hline 2 & AF & 90,5 & Tinggi \\
\hline 3 & EDN & 82,5 & Tinggi \\
\hline 4 & YE & 61 & Sedang \\
\hline 5 & AP & 26,1 & Rendah \\
\hline
\end{tabular}


Vol 2 No 2 Desember 2021

Jurnal AlphaEuclidEdu

Received: 02/03/2021; Resived: 23/09/2021; Accepted: 28/12/2021

\begin{tabular}{|c|c|c|c|}
\hline 6 & SA & 54,5 & Sedang \\
\hline 7 & KM & 27 & Rendah \\
\hline 8 & PGE & 62,5 & Sedang \\
\hline 9 & RSH & 59,6 & Sedang \\
\hline 10 & AN & 68,2 & Sedang \\
\hline 11 & MOM & 66,8 & Sedang \\
\hline 12 & MW & 66,4 & Sedang \\
\hline 13 & SN & 57,4 & Sedang \\
\hline 14 & SM & 53,7 & Sedang \\
\hline 15 & U & 64,2 & Sedang \\
\hline 16 & HS & 81,6 & Tinggi \\
\hline 17 & FYNA & 80,4 & Tinggi \\
\hline
\end{tabular}

Berdasarkan tabel 1 dari 17 peserta didikdiperoleh 4 peserta didik yang memiliki tingkat kecerdasan emosional tinggi, 11 peserta didik dengan kecerdasan emosional tingkat sedang dan 2 peserta didik dengan kecerdasan emosonal tingkat rendah.

\section{Literasi Numerasi}

Selain angket kecerdasanemosional, tes literasi numerasi juga merupakan salah satu instrumen dalam pengumpulan data dalah penelitian ini. Tes berupa soal literasi dengan materi persamaan dan pertidaksamaan nilai mutlak linear satu variabel. Berikut merupakan hasil dari tes literasi numerasi dengan jumlah soal sebanyak 4 soal.

Tabel 2. Hasl Perolehan Skor Literasi Numerasi

\begin{tabular}{|c|c|c|c|c|c|c|}
\hline \multirow[t]{2}{*}{ No } & \multirow[t]{2}{*}{ Nama } & \multicolumn{4}{|c|}{$\begin{array}{c}\text { Skor Literasi Numerasi } \\
\text { Per Soal }\end{array}$} & \multirow[t]{2}{*}{ Jumlah } \\
\hline & & 1 & 2 & 3 & 4 & \\
\hline 1 & ATA & 2 & 4 & 2 & 1 & 7 \\
\hline 2 & $\mathrm{AF}$ & 6 & 6 & 6 & 6 & 24 \\
\hline 3 & EDN & 6 & 6 & 6 & 6 & 24 \\
\hline 4 & YE & 4 & 1 & 3 & 2 & 9 \\
\hline 5 & $\mathrm{AP}$ & 2 & 0 & 1 & 1 & 2 \\
\hline 6 & SA & 4 & 3 & 4 & 1 & 9 \\
\hline 7 & KM & 2 & 1 & 1 & 1 & 4 \\
\hline 8 & PGE & 5 & 2 & 2 & 1 & 8 \\
\hline 9 & RSH & 5 & 1 & 3 & 1 & 9 \\
\hline 10 & AN & 2 & 5 & 6 & 6 & 19 \\
\hline 11 & MOM & 4 & 4 & 4 & 4 & 16 \\
\hline 12 & MW & 4 & 1 & 2 & 1 & 7 \\
\hline 13 & SN & 4 & 3 & 1 & 1 & 6 \\
\hline 14 & SM & 5 & 5 & 2 & 1 & 13 \\
\hline 15 & $\mathrm{U}$ & 4 & 5 & 4 & 1 & 13 \\
\hline 16 & HS & 6 & 5 & 5 & 6 & 22 \\
\hline 17 & FYNA & 6 & 6 & 6 & 6 & 24 \\
\hline
\end{tabular}

Berdasarkan tabel 2 hasil perolehan skor literasi numerasi pada materi persamaan dan pertidaksamaan nilai mutlak linear satu variabel dapat dilihat bahwa 
Vol 2 No 2 Desember 2021

Jurnal AlphaEuclidEdu

Received: 02/03/2021; Resived: 23/09/2021; Accepted: 28/12/2021

29,4\% peserta didik memiliki literasi numerasi baik, 41,1\% peserta didik memiliki numerasi cukup baik dan 29,4\% peserta didik memiliki literasi numerasi kurang baik. Dari hasil pencapaian skor yang ada, ada 3 indikator yang dijadikan dasar penilaian literasi numerasi yaitu peserta didik mampu menggunakan berbagai macam angka dan simbol-simbol yang terkait dengan matematika dasar untuk memecahkan permasalahan kontekstual dan menganalisis informasi yang berbentuk grafik, tabel, bagan, dll serta menggunakan interpretasi dan mengkomunikasikan hasil analisis tersebut untuk memprediksi dan mengambil kesimpulan akhir. Berikut merupakan pencapaian indikator literasi numerasi pada peserta didik kelas X IPA 3. 
Vol 2 No 2 Desember 2021

Jurnal AlphaEuclidEdu

Received: 02/03/2021; Resived: 23/09/2021; Accepted: 28/12/2021

Tabel 3. Pencapaian Indikator Literasi Numerasi

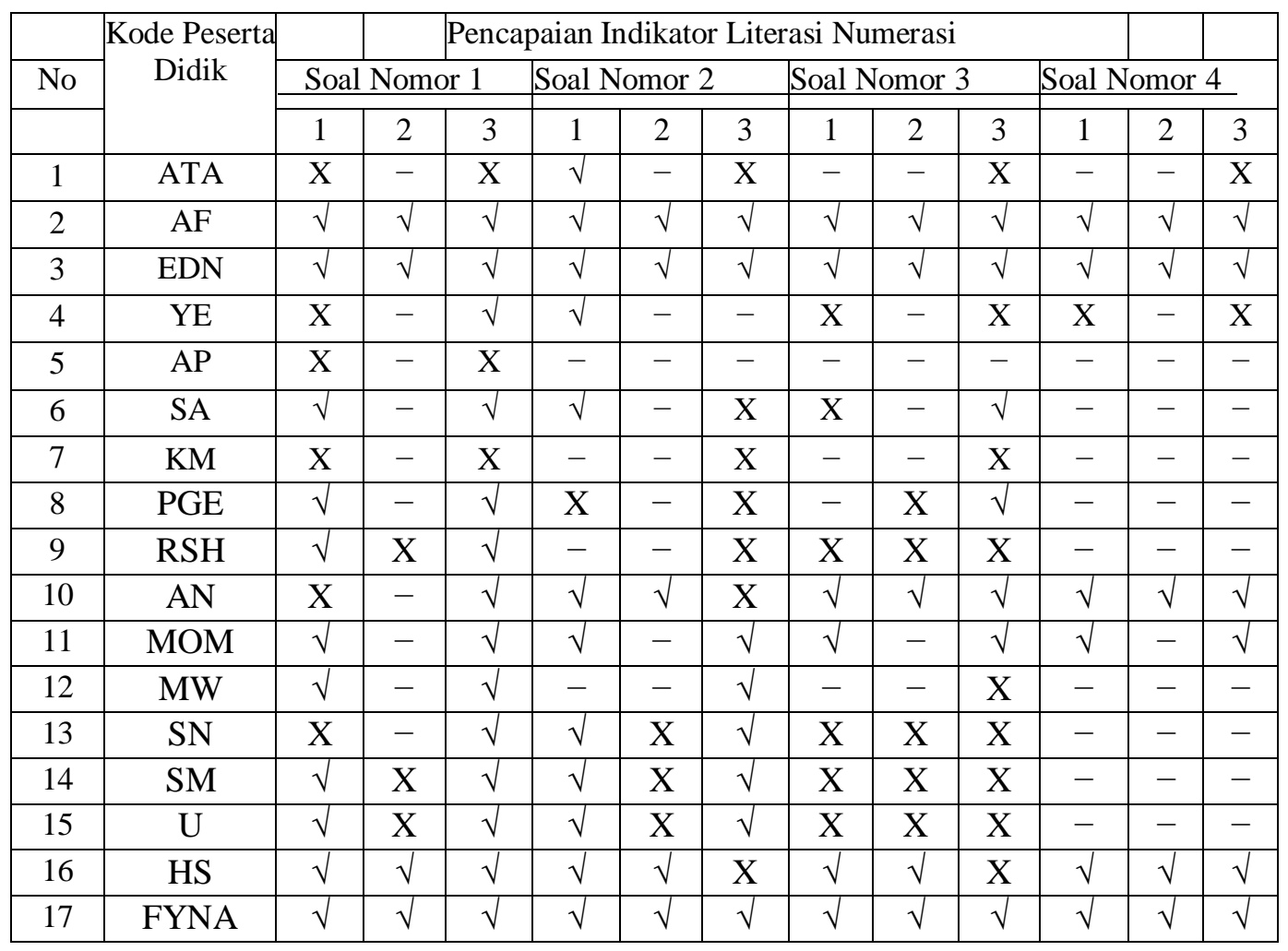

\section{Literasi Numerasi Dikaji Dari Kecerdasan Emosional Peserta didik}

a. Literasi Numerasi Peserta Didik Dengan Kecerdasan Emosional TingkatTinggi

Berdasarkan hasil tes literasi numerasi yang dilakukan terhadap 17 peserta didik, ada empat peserta didik yang memiliki kecerdasan emosional tingkat tinggi yaitu peserta didik dengan kode AF, EDN, HS dan FYNA. Dilihat dari hasil tes, peserta didik yang memiliki kecerdasan emosional tingkat tinggi juga memiliki literasi numerasi yang sangat baik. Seperti dari hasil tes AF, EDN dan FYNA yang mencapai maksimal dari skor tes yaitu 24. Ketiga peserta didik ini dapat menjawab tesdengan baik dan benar sesuai dengan indikator yang diujikan.

b. Literasi Numerasi Peserta Didik Dengan Kecerdasan Emosional TingkatSedang Berdasarkan hasil tes literasi numerasi yang diberikan kepada 17 peserta didik, ada 11 peserta didik dengan tingkat kecerdasan emosional sedang yaitu ATA, YE, SA, PGE, RSH, AN, MOM, MW, SN, SM, dan U. Dari kesebelas peserta didik ini memperoleh hasil tes yang bervariasi. Seperti halnya pada peserta didik dengan kode AN, iamemperoleh hasil tes yang bagus yaitu 19 untuk AN. Selain itu, terdapat juga peserta didik yang memperoleh hasil tes yang cukup seperti YE, SA, RSH, MOM, SM, dan U. Hasil tes literasidari keenam peserta didik ini, adasekitar empat peserta didik yang belum mampu mencapai indicator menganalisis informasi yang ditampilkan dalam berbagai bentuk yaitu MOM, YE, RSH, dan SM. Peserta didik yang memiliki tingkat kecerdasan emosional sedang juga ada yang memperoleh hasil tes literasi numerasi yang kurang baik yaitu MW, ATA, PGE dan SN dimana 
Vol 2 No 2 Desember 2021

Jurnal AlphaEuclidEdu

Received: 02/03/2021; Resived: 23/09/2021; Accepted: 28/12/2021

peserta didik ini belum mampu mencapai keseluruhan indikator yang ada.

c. Literasi Numerasi Peserta Didik dengan Kecerdasan Emosional Tingkat Rendah

Berdasarkan hasil tes literasi numerasi yang diberikan kepada 17 peserta didik, ada dua peserta didik yang memilikikecerdasan emosional tingkat rendah yaitu AP dan KM. Dari hasil pengerjaan soal tes literasi numerasi menunjukan bahwa peserta didik yang memiliki tingkat kecerdasan emosionalrendah secara keseluruhan hasil tes literasi numerasinya juga kurang baik.

\section{Pembahasan}

Kecerdasan emosional adalah kemampuan individu dalam mengenali perasaan diri sendiri dan perasaan orang lain, mampu memotivasi diri sendiri, mampu mengolah emosi dan dapat berhubungan sosial yang baik dengan sesamanya. Menurut Aunurrahman (2008: 69) kecerdasan emosional tidak kalah penting dengan kecerdasan akademik, kecerdasan emosional membuat seseorang mampu melihat masalah, mampu mengatasi kegagalan dan akan mencapai kesuksesan. Jadi dengan dimilikinya kecerdasan emosional yang baik dapat membantu seseorang mencapai kesuksesannya. Menurut Goleman (dalam Prawira, 2011: 159) kesuksesan peserta didik didukung dari $20 \%$ kecerdasan akademik dan 80\% merupakan kecerdasan lain yang disebut kecerdasan emosional. Dalam penelitian ini, kita akan melihat literasi numerasi peserta didik yang dikaji dari tingkatan kecerdasan emosional peserta didik tersebut. Literasi numerasi termasuk dalam literasi matematika, dimana literasi ini memerlukan kemampuan berpikir tingkat tinggi. Dilihat dari pendapat para ahli diatas mengennai kecerdasan emosional yang berpengaruh dalam kesuksesan belajar peserta didik, maka dapat disimpulkan juga jika peserta didik memiliki kecerdasan emosional yang baik maka peserta didik tersebut dapat menyelesaikan permasalahan matematika yang menuntut peserta didik memiliki kemampuan berpikir matematika tingkat tinggi. Atau dapat diperjelas jika peserta didik memiliki kecerdasan emosional baik maka kemampuan literasi pesertadidik tersebut juga baik.

Literasi numerasi pada materi persamaan dan pertidaksamaan nilai mutlak linear satu variabel pada peserta didik yang memiliki tingkat kecerdasan emosional rendah juga cendrung rendah. Peserta didik yang tergolong dalamkecerdasan emosional tingkat rendah ada dua orang yaitu AP dan KM. Hasil yang diperoleh dari kedua peserta didik itu adalah 2 untuk AP dan 4 untuk KM. Dilihat dari hasil maksimal tes literasi numerasi ialah 24 hasil yang diperoleh dari kedua peserta didik ini dapat dikatakan rendah. Dapat dilihat bahwa hasil penelitian sesuai dengan teori yang ada. Literasi numerasi pada peserta didik dengan tingkat kecerdasan emosional sedang sangat bervariasi dapat dilihat bahwa ada peserta didik yang memiliki literasi numerasi yang baik yaitu AN. Hasil yang diperoleh AN dapat digolongkan baik karena sebagian besar indikator dapat tercapai. Selain itu pada peserta didik lain ada enam orang yang memiliki literasi numerasi yang cukup baik, peserta didik ini sudah cukup mampu dalam mencapai indikator yang ada walaupun ada beberapa indikator yang masih belum tercapai. Kemudian empat orang diantara peserta didik yang memiliki kecerdasan emosional tingkat sedang memiliki literasi numerasi yang kurang baik, keempat peserta didik ini belum mampu mencapai sebagian besarindikator yang ada. Hasil penelitianpada tingkat kecerdasan emosionalsedang tidak sesuai dengan teori yang ada. Literasi numerasi pada peserta didik yang memiliki kecerdasan emosioanal tingkat tinggi memiliki literasi numerasi yang baik. Dilihat dari hasil tes dimana keempat peserta didik ini sudah 
Vol 2 No 2 Desember 2021

Jurnal AlphaEuclidEdu

Received: 02/03/2021; Resived: 23/09/2021; Accepted: 28/12/2021

mampu mencapai seluruhindikator yang ada, walaupun pada peserta didik HS terdapat kekeliruan sedikit pada salah satu indikator yang ada. Hal ini dapat dikatakan hasil penelitian sesuai dengan teori yang ada.

Dari Hasil dan pembahasan dalam penelitian ini dapat dilihat bahwa tidak selalu peserta didik yang memiliki kecerdasan emosional sedang juga memiliki literasi numerasi yang cukup baik. Dari hasil penelitian peserta didik dengan tingkat kecerdasan emosional sedang juga memiliki literasi yang baik dan kurang baik pula.

Pada kecerdasan emosional tingkat sedang memiliki literasi numerasi yang bervariasi. Pada teori yang ada, seharusnya kercerdasan emosional tingkat sedang memiliki literasi numerasi yang cukup baik. Namun, pada kenyataan dalam penelitian ini tidak sesuai dengan teori. Dilihat dari hasil tes literasi banyak peserta didik yang mengalami kesulitan dalam mengerjakannya. Didukung juga dalam wawancara dengan salah seorang peserta didik, ia mengatakan jika ia merasa kesulitan dalam mengerjakan pada soal nomor 4. Sehingga pada saat mengerjakan ada yang melihat google ataupun bertanya pada teman yang lain, karena tes dilakukan secara online. Selain itu, banyak peserta didik yang tidak teliti dalam mengerjakan soal- soal literasi numerasi. Dilihat dari hasil tes ada yang hanya menjawab sebagian saja dan terburu-buru dalam mengerjakan, karena pada saat tes ada waktu pengumpulan dan peserta didik banyak juga yang mengalami masalah dalam jaringan.

\section{Kesimpulan dan Saran Kesimpulan}

Berdasarkan hasil penelitian dan pembahasan pada bab IV, maka dapat disimpulkan bahwa: Kecerdasan emosional tingkat rendah pada dua orang peserta didik cenderung memiliki literasi numerasi kurang baik, dikarenakan dua peserta didik ini belum mampu mencapai dari ketiga indikator yang ada, yaitu belum mampu menggunakan berbagai macam angka dan simbol-simbol yang terkait dengan matematika dasar untuk memecahkan masalah kontekstual, menganalisis informasi yang ditampilkan dalam berbagai bentuk, dan menggunakan interpretasi dan mengkomunikasikan hasil analisis untukmemprediksi dan mengambilkesimpulan.

Kecerdasan emoisonal tingkat sedang pada sebelas orang peserta didik memiliki literasi numerasi yang bervariasi, yaitu satu orang dengan literasi numerasi yang baik, mampu mencapai dari ketiga indikator yang ada. Ada enam orang dengan literasi numerasi yang cukup baik, mampu mencapai beberapa indikator yang ada dalam literasi numerasi. Contohnya pada peserta didik dengan kode MOM, dimana peserta didik ini hanya mampu mencapai dua indikator saja yaitu mampu menggunakan berbagai macam angka dan simbol-simbol yang terkait dengan matematika dasar untuk memecahkan masalah kontekstual dan mampu menggunakan interpretasi dan mengkomunikasikan hasil analisis untukmemprediksi dan mengambilkesimpulan.

Empat orang dengan literasi numerasi yang kurang baik, dimana subjek belum mampu mencapai seluruh indikator yang ada. Jadi tidak semua peserta didik yang tergolongdalam kecerdasan emosional tingkat sedang memiliki literasi yang cukup baik. Kecerdasan emosional tingkat tinggi pada empat orang peserta didik cenderung memiliki literasi numerasi yang baik, yaitu mampu mencapai seluruh indikator yang dimaksud.

\section{Saran}

Beberapa saran yang dapat penulis sampaikan berdasarkan hasil temuan dalam 
Vol 2 No 2 Desember 2021

Jurnal AlphaEuclidEdu

Received: 02/03/2021; Resived: 23/09/2021; Accepted: 28/12/2021

penelitian ini yaitu: a) Hasil penelitian ini menunjukan bahwa kecerdasan emosional subjek penelitian tergolong sedang atau dapat dikatakan sudah baik. Oleh karena itu kepada pengajar di SMAS Panca Setya Sintang, orang tua dan orang-orang yang berkewajiban agar dapat mempertahankan terus pola-pola bimbingan dan penghargaannya selama ini, sambil tersu menambah informasi yang berkaitan dengan kecerdasan emosional, sehingga diharapkan akan lebih efektif dalam membantu pengembangan diri peserta didik; b) Hasil penelitian ini menunjukan bahwa literasi numerasi subjek penelitian tergolong sedang. Dengan demikiandiharapkan kepada guru untukmempertahankan pengajaran didalamkelas, sambil meningkatkan literasi numerasi peserta didik dengan latihan- latihan soal kontekstual yang diharapkan mampu membantu peserta didik meningkatkan literasi numerasi.

\section{Referensi}

Aunurrahman. 2008. Belajar danPembelajaran. Bandung: Alfabeta.

Darmawati. (2020). Matematika Dengan Metode Tutor Sebaya. 1(2), 49-58.

Elviani, D. (2020). Vol 1, No 1: 2020. Jurnal AlphaEuclidEdu, 1(1), 1-8. https://doi.org/10.21428/8c841009.086f1532

Fitriawan, D. (2004). Strategi Reorientasi Kurikulum Pendidikan Matematika Di Era Revolusi Industri 4.0. Jurnal Pengabdi, 4, 300.

Fitriawan, D. (2021). Ekplorasi Bahan Ajar Geometri Dalam Kesinambungan Diskursus Matematika. Jurnal Derivat: Jurnal Matematika Dan Pendidikan Matematika, 8(1), 11-20. https://doi.org/10.31316/j.derivat.v8i1.1332.

Kemendikbud. 2017. Gerakan Literasi Nasional. Jakarta: Kemendikbud. Online. Diakses 1 September 2020.

Kurniasih, A.W. \& Wardono. 2015. Peningkatan Literasi Matematika Mahasiswa Melalui Pembelajaran Inovatif Realistik E-learning Edmodo Bermuatan Karakter Cerdas Kreatif Mandiri. Jurnal Matematika Kreatif- Inovatif.6(1) : 93 - 100 OECD. (2016). PISA 2015 Results in Focus. New York: Columbia University.

Panjaitan, S., Hartoyo, A., \& Fitriawan, D. (2021). Eksplorasi Etnomatematika Kain Tenun Songket Suku Melayu Sambas. Jurnal AlphaEuclidEdu, 2(1), 19-31. https://jurnal.untan.ac.id/index.php/AlphaEuclidEdu/article/view/47890

Prawira, Purwa Atmaja. 2011. Psikologi Pendidikan dalam Perspektif Baru. Jogjakarta: Ar Ruzz Media. 